\title{
Internalisasi Kearifan Lokal Dalam Pembelajaran melalui Pengembangan Multimedia Interaktif Muatan Pembelajaran IPS
}

\author{
Didit Satya Prayogi ${ }^{1}$, Sugeng Utaya ${ }^{2}$, Sumarmi $^{2}$ \\ ${ }^{1}$ Pendidikan Dasar-Universitas Negeri Malang \\ ${ }^{2}$ Pendidikan Geografi-Universitas Negeri Malang
}

\begin{tabular}{l}
\hline \hline INFO ARTIKEL \\
\hline Riwayat Artikel: \\
Diterima: 16-05-2019 \\
Disetujui: $12-11-2019$ \\
\hline
\end{tabular}

\section{Kata kunci:}

local wisdom; interactive multimedia; social studies learning; kearifan lokal; multimedia interaktif; pembelajaran IPS

\author{
Alamat Korespondensi: \\ Didit Satya Prayogi \\ Pendidikan Dasar \\ Universitas Negeri Malang \\ Jalan Semarang 5 Malang \\ E-mail: diditsatya.spd@gmail.com
}

\begin{abstract}
ABSTRAK
Abstract: Internalization of local wisdom in learning through the development of interactive multimedia is an effort made to instill a critical and proud attitude towards the culture of the region from an early age. The values of local wisdom of Berau Regency are packaged in the form of interactive multimedia with an interesting following the progress of the times where the use of information technology is a support for learning that is widely used today. The purpose of research and development is to see the response of teachers and students to interactive multimedia, and to see the effectiveness of interactive multimedia to support learning. the results of the study found positive responses and increased student learning outcomes after using interactive multimedia based on local wisdom in the learning process.

Abstrak: Internalisasi kearifan lokal dalam pembelajaran melalui pengembangan multimedia interaktif adalah upaya yang dilakukan untuk menanamkan sikap kritis dan bangga terhadap budaya daerahnya sejak dini. Nilai-nilai kearifan lokal Kabupaten Berau dikemas dalam bentuk multimedia interaktif dengan menarik mengikuti kemajuan zaman, dimana penggunaan teknologi informatika merupakan penunjang pembelajaran yang banyak digunakan saat ini. Tujuan penelitian dan pengembangan untuk melihat respons guru dan siswa terhadap multimedia interaktif, dan untuk melihat keefektifan dari multimedia interaktif menunjang pembelajaran. Hasil dari penelitian ditemukan respons positif dan peningkatan hasil belajar siswa setelah menggunakan multimedia interaktif berbasis kearifan lokal dalam proses pembelajaran.
\end{abstract}

Pendidikan yang berkelanjutan memiliki peranan penting dalam mencerdaskan kehidupan bangsa untuk membentuk dan menghasilkan generasi masa depan yang berkarakter serta berbudi luhur, menurut pendapat yang dikemukakan oleh (Sumarmi \& Amirudin, 2014) Pendidikan dapat dikatakan sebagai upaya rekonstruksi nasional untuk pembangunan yang berkelanjutan. Sehingga penting untuk melaksanakan pendidikan dengan melakukan perencanaan yang matang dan merefleksi dengan baik setiap kegiatan berhubungan dengan proses pendidikan. Dalam hal ini khususnya, berkaitan dengan guru dan siswa. Karena tingkat kebermutuan pendidikan bergantung kepada keberadaan guru dan interaksi yang dilakukan dengan siswa. Sependapat dengan hal tersebut (Jossapat, Hendra, 2015) mengatakan bahwa di dalam proses pembelajaran guru memegang posisi yang strategis, dimana guru berperan sebagai fasilitator bagi siswa agar siswa mampu mengembangkan kemampuan dan mengonstruksi pengetahuannya melalui proses pembelajaran bermakna.

Suatu pembelajaran bermakna dilakukan bukan hanya untuk penguasaan teori, namun juga implementasinya dalam kehidupan sehari-hari. Untuk memberikan pemahaman kepada siswa maka perlu dukungan dari sumber belajar dan metode pembelajaran yang tepat. Sumber belajar yang potensial ialah berkaitan dengan unsur lingkungan sekitar siswa. Belajar akan menjadi lebih bermakna bagi siswa, jika materi pembelajaran kontekstual dengan lingkungan dan pengalaman yang dilihat langsung oleh siswa dalam kesehariannya. Menurut pendapat (Komalasari, 2014) mengatakan bahwa pembelajaran kontekstual merupakan pendekatan pembelajaran dengan mengaitkan materi yang dipelajari dengan kehidupan nyata siswa sehingga terciptanya kebermaknaan dalam pembelajaran. Dapat dikatakan pembelajaran bermakna terwujud melalui pembelajaran kontekstual yang berupaya untuk memahami makna hubungan antara materi pembelajaran dengan kehidupan di sekitar siswa. Maka dari itu pembelajaran kontekstual menunjang untuk diimplementasikannya wawasan pengetahuan yang berkaitan dengan keunikan daerah setempat maupun potensi-potensi yang ada di sekitar tempat tinggal siswa. 
Memanfaatkan keunikan daerah setempat maupun potensi-potensi yang ada di daerah sekitar siswa dapat menjadi suatu alternatif bagi guru untuk mengajarkan nilai-nilai kearifan lokal dari budaya lokal di daerah tersebut. (Panen \& Sardiyo, 2005) memberi saran agar pendidikan yang berbasis budaya lokal dibawa ke pembelajaran agar lingkungan belajar menjadi lebih menarik dan menyenangkan baik bagi guru maupun siswa sehingga memungkinkan siswa terlibat aktif di dalam pembelajaran dan siswa mampu mencapai kompetensi yang ditentukan. Kearifan lokal adalah identitas yang hanya dimiliki oleh suatu daerah setempat dan berbeda dengan daerah lainnya. Kearifan lokal atau istilah lainnya local wisdom (kearifan setempat) secara umum memiliki arti sebagai gagasan-gagasan setempat (local) yang bersifat bijaksana, bernilai baik, yang tertanam dan diikuti oleh anggota masyarakatnya secara turun temurun. Menurut (Sudikan \& Setya, 2013) menyatakan bahwa kearifan lokal selalu dikaitkan dengan adanya pola hubungan kehidupan masyarakat atau komunitas setempat dalam menjalin hubungan antara individu dengan dirinya sendiri, individu dengan orang lain sebagai makhluk sosial, individu dengan alam, serta individu dengan sang pencipta.

Salah satu bagian dari kearifan lokal ialah local genius. Local Genius merupakan suatu kemampuan yang dimiliki oleh masyarakat lokal dalam upaya memfilter pengetahuan, pandangan, sikap, dan pengaruh dari kebudayaan baru atau asing (Rosidi, 2011). Dapat dipahami kearifan lokal sebagai perilaku positif, nilai dan norma yang berkembang secara turun-temurun di masyarakat tertentu. Nilai-nilai yang khas dan unik dalam budaya lokal atau daerah setempat menjadi hal yang patut dipertahankan dan tetap diajarkan ke generasi muda sebagai pengetahuan dan salah satu sumber belajar. Sebagaimana pendapat yang dikemukakan oleh (Utari, Degeng, \& Akbar, 2016) menyatakan bahwa untuk menciptakan suatu pembelajaran yang kontekstual dapat dilakukan melalui penanaman nilai-nilai kearifan lokal dimana siswa berada. hal ini bermanfaat untuk mempertahankan dan melestarikan kebudayaan lokal sehingga proses pembelajaran menjadi lebih bermakna bagi siswa.

Kearifan lokal di daerah Kabupaten Berau yang dipilih dalam penelitian pengembangan ini berkaitan dengan sejarah Kabupaten Berau, kondisi geografis kenampakan alam, makanan tradisional, benda bersejarah, seni musik, cerita rakyat Baddit Dipatung, ritual adat Manguati Banua merupakan acara yang bertujuan untuk menghindarkan dari segala musibah. Dimana melalui acara ini masyarakat Berau diajak untuk menjaga dan menghormati alam (Kaltim Prokal, 2016). Tradisi Baturunan Parau dahulu acara ini dilakukan saat memasuki masa panen masyarakat Berau menggelar syukuran dan mendoakan perahu yang digunakan untuk panen, karena akses transportasi darat belum terbuka sehingga untuk memanen padi masyarakat bergotong royong menurunkan perahu panjang dari rumah kesultanan. Kini akses darat sudah terbuka namun nilai-nilai kegotong royongan masyarakat tetap dipertahankan melalui Baturuan Parau hanya saja bukan untuk panen namun dijadikan ajang perlombaan perahu panjang antar kampung (Berau Prokal, 2015). Seni beladiri Kuntaw olahraga beladiri asli yang dimiliki oleh Kabupaten Berau namun kini sudah sangat sedikit anak muda yang berlatih Kuntaw dikhawatirkan nilai sejarahnya akan menghilang begitu saja. pendapat (Suwaryo, 2008) menyatakan bahwa pencak silat dapat diklarifikasikan ke dalam wujud kebudayaan yang berupa seni beladiri dengan pola-pola tertentu dan memiliki adat tata kelakuan tersendiri sehingga perlu adanya upaya untuk pelestarian.

Pada jenjang sekolah dasar aspek-aspek kearifan lokal tersebut merupakan bagian dari muatan pembelajaran IPS. (Khuriyah, Utaya, \& Sapto, 2016) perilaku sosial, ekonomi, dan budaya manusia di masyarakat dalam konteks ruang dan waktu yang mengalami perubahan merupakan ruang lingkup IPS dimana masyarakat menjadi sumber utama pembelajaran IPS itu sendiri. Materi IPS khususnya aspek kearifan lokal merupakan materi yang abstrak sementara siswa pada rentang umur 6-12 tahun pola berpikir anak masih di tahap operasional konkret. Agar konsep kearifan lokal yang abstrak tersebut dapat di internalisasikan pada anak sekolah dasar dibutuhkan suatu media pendukung pembelajaran menarik, mudah dipahami, serta menyenangkan. Karakteristik dari multimedia interaktif dirasakan yang paling tepat dengan kebutuhan tersebut. Multimedia interaktif merupakan suatu tampilan multimedia yang dirancang oleh desainer agar tampilannya memenuhi fungsi untuk menginformasikan pesan dan memiliki interaktivitas kepada (user) penggunanya (Munir, 2013). Penggabungan antara materi pembelajaran dengan kearifan lokal menggunakan media pembelajaran memberikan dasar dan pengetahuan yang dekat dengan dunia siswa (Noviana \& Bakri, R, 2015; Sukmawati, Utaya, \& Susilo, 2015). Internalisasi kearifan lokal meningkatkan minat belajar siswa. CD pembelajaran berbasis kearifan lokal memperoleh kriteria sangat baik sehingga minat siswa terhadap pembelajaran menggunakan CD pembelajaran sangat tinggi (Damayanti, Dewi, \& Akhlis, 2013).

Penelitian pengembangan ini menghasilkan multimedia interaktif berbasis kearifan lokal Kabupaten Berau. adapun pengembangan yang dilakukan bertujuan untuk mengetahui respons guru dan siswa saat proses pembelajaran menggunakan multimedia interaktif berbasis kearifan lokal Kabupaten Berau yang ditinjau dari aspek kepraktisan dan kemenarikan. Menginternalisasikan kearifan lokal Kabupaten Berau ke dalam multimedia interaktif dapat menumbuhkan rasa cinta dan tanggung jawab untuk menjaga alam, budaya, tradisi, maupun peninggalan bersejarah lainnya. Selain itu, tuntutan global mengharuskan pendidikan senantiasa menyesuaikan perkembangan teknologi dalam upaya meningkatkan mutu pendidikan, terutama penggunaan TIK dalam bidang pendidikan, khususnya dalam proses pembelajaran (Rusman, 2010). 


\section{METODE}

Penelitian ini merupakan jenis penelitian dan pengembangan (Research and Development), penelitian dan pengembangan ini adalah metode penelitian yang dilakukan untuk menghasilkan produk tertentu serta menguji keefektifannya (Sugiyono, 2015). Penelitian pengembangan yang dilakukan menggunakan model pengembangan Lee \& Owens (2014). Model pengembangan Lee \& Owens dipilih karena sintaks yang dimiliki oleh model tersebut dianggap tepat dan sesuai untuk tahapan mengembangkan produk berbasis multimedia interaktif, tahapan penelitian Lee \& Owens yang terdiri dari lima langkah dapat membantu untuk menghasilkan produk multimedia yang layak, menarik, praktis, dan efektif untuk digunakan. Adapun langkah dari model pengembangan Lee \& Owens, yakni need assesment, design, development, implementation, evaluation.

Tahap need assesment terdiri dari dua langkah yaitu, melakukan, analisis kebutuhan dengan memperhatikan kondisi lapangan, observasi, maupun wawancara dengan narasumber. Melakukan analisis awal - akhir (front-end analysis) tahapan ini terdiri dari delapan langkah analisis yang dilakukan secara menyeluruh. Pertama, analisis tujuan dilakukan untuk menentukan tujuan pembelajaran yang akan dicapai setelah menggunakan multimedia interaktif. Kedua, analisis siswa dilakukan untuk mengidentifikasi karakteristik subjek penelitian siswa kelas IV. Ketiga, situasi dilakukan untuk mengidentifikasi lingkungan belajar siswa dan gaya belajarnya. Keempat, analisis media dilakukan untuk mengidentifikasi media yang sesuai dengan kebutuhan siswa. Kelima, analisis teknologi dilakukan untuk mengidentifikasi sarpras teknologi yang dimiliki sekolah. Keenam, tugas dilakukan untuk menentukan tugas yang akan diberikan siswa mengacu kepada KI \& KD berdasarkan kurikulum. Ketujuh, analisis kejadian penting dilakukan untuk menentukan materi yang disajikan dalam multimedia 8. Analisis data dilakukan untuk mengidentifikasi dan mengumpulkan sumber dan bahan pembelajaran yang relevan.

Tahap design melakukan perencanaan untuk pengembangan produk, langkah pada tahap design, yaitu menentukan jadwal pengembangan, menyusun tim proyek yang terdiri dari peneliti sebagai pengembangan, dosen pembimbing 1 dan 2 , serta validator ahli media dan validator materi, menyusun spesifikasi media, dan menyusun struktur materi sesuai dengan muatan pembelajaran IPS yang terdapat di buku tematik tema 8 daerah tempat tinggalku serta melakukan analisis SK, KI \& KD. Tahapan selanjutnya ialah tahap Development membuat story board sebagai pedoman untuk menggabungkan seluruh elemen penyusun dari multimedia interaktif, membuat, dan memasukan komponen multimedia. Mulai dari materi pembelajaran, gambar, animasi, suara, video, dan musik. Multimedia yang telah selesai dibuat dalam bentuk Compact Disc (CD). Sebelum produk di uji coba di lapangan, terlebih dahulu multimedia melalui uji kelayakan yang divalidasi oleh validator ahli media dan ahli materi

Tahap Implementation melakukan uji coba kelompok kecil dan uji coba lapangan untuk memperoleh data respons guru dan siswa, serta keefektifan produk yang dikembangkan. Tahap Evaluation melakukan evaluasi secara keseluruhan berkaitan dengan data-data yang telah diperoleh serta fungsionalitas multimedia interaktif dari segi kelayakan, kemenarikan, kepraktisan dan keefektifan. Jika ditemukan revisi maka akan dilakukan perbaikan. Berikut instrumen pengumpulan data yang digunakan sebagai acuan untuk melakukan evaluasi pada tabel 1.

Tabel 1. Instrumen Pengumpulan Data

\begin{tabular}{|c|c|c|c|c|}
\hline Tujuan & Aspek yang diukur & Instrumen & Data yang diperoleh & Responden \\
\hline \multirow[t]{6}{*}{$\begin{array}{l}\text { Kelayakan produk multimedia } \\
\text { interaktif }\end{array}$} & Kelayakan produk & $\begin{array}{l}\text { Angket } \\
\text { Validasi }\end{array}$ & Validitas multimedia interaktif & $\begin{array}{l}\text { Ahli materi } \\
\text { Ahli materi }\end{array}$ \\
\hline & \multirow[t]{2}{*}{ Kemenarikan produk } & $\begin{array}{l}\text { Angket } \\
\text { praktisi }\end{array}$ & Respons guru terhadap produk multimedia interaktif & Guru \\
\hline & & $\begin{array}{l}\text { Angket } \\
\text { siswa }\end{array}$ & $\begin{array}{l}\text { Respons siswa setelah menggunakan produk } \\
\text { multimedia interaktif }\end{array}$ & Siswa \\
\hline & \multirow[t]{2}{*}{ Kepraktisan produk } & $\begin{array}{l}\text { Angket } \\
\text { praktisi }\end{array}$ & $\begin{array}{l}\text { Kemudahan guru dalam mengoperasikan } \\
\text { multimedia interaktif }\end{array}$ & Guru \\
\hline & & $\begin{array}{l}\text { Angket } \\
\text { siswa }\end{array}$ & $\begin{array}{l}\text { Kemudahan siswa dalam mengoperasikan secara } \\
\text { mandiri }\end{array}$ & Siswa \\
\hline & Keefektifan produk & $\begin{array}{l}\text { Lembar } \\
\text { evaluasi }\end{array}$ & Hasil belajar siswa & Siswa \\
\hline
\end{tabular}

Teknik analisis data menggunakan analisis data deskriptif kualitatif dan data kuantitatif. Data kualitatif diperoleh dari hasil yang didapatkan saat melakukan observasi, wawancara, dan catatan berupa saran yang diperoleh berdasarkan instrumen pengumpulan data, sedangkan data kuantitatif diperoleh dari hasil yang dikumpulkan dari skors angket secara keseluruhan dari masing-masing instrumen. Adapun rumus yang digunakan pada tabel 2. 
Tabel 2. Rumus Menghitung Persentase Hasil Data

\begin{tabular}{|l|l|}
\hline Ps $=\frac{\Sigma x}{\Sigma x S} \times 100 \%$ & Keterangan \\
& Ps = Persentase (hasil yang dicari) \\
& $\sum \mathrm{x}=$ Jumlah keseluruhan jawaban \\
& $\sum \mathrm{xs}=$ Jumlah keseluruhan skor ideal \\
& $100 \%=$ Konstanta \\
\hline
\end{tabular}

Sumber : diadaptasi dari (Akbar, 2017)

Pengumpulan data uji keefektifan multimedia interaktif berbasis kearifan lokal Kabupaten Berau dilakukan melalui evaluasi pre-Test dan post-Test (sebelum menggunakan produk dan setelah menggunakan produk). Hasil dari kedua tes tersebut kemudian dibandingkan setelah menginternalisasikan kearifan lokal Kabupaten Berau di dalam proses pembelajaran. Soal-soal yang terdapat di dalam lembar evaluasi berkaitan dengan materi tema 8 Daerah Tempat Tinggal. Subjek pada penelitian ini melibatkan siswa kelas IV SDN 002 Tanjung Redeb dengan tingkat prestasi yang heterogen. Uji kelompok kecil melibatkan delapan orang siswa dan uji lapangan melibatkan siswa sebanyak 28 orang siswa.

\section{HASIL DAN PEMBAHASAN}

Paparan hasil data disajikan setalah data-data hasil penelitian yang dimulai dari tahapan awal melakukan analisis kebutuhan, uji kelayakan, uji kelompok kecil hingga uji lapangan telah dianalisis secara keseluruhan. Penelitian ini dimulai pada bulan Desember akhir 2017-April 2019. Hasil analisis kebutuhan secara garis besar berdasarkan hasil observasi menunjukkan bahwa sekolah yang bersangkutan yaitu SDN 002 Tanjung Redeb telah memiliki sarana dan prasaran memadai untuk melakukan pembelajaran dengan menggunakan multimedia, terdapat laptop dan LCD proyektor yang dapat digunakan oleh guru untuk kegiatan pembelajaran. Proses pembelajaran masih ditunjang buku tematik belum terlihat guru menggunakan media penunjang pembelajaran lainnya seperti multimedia interaktif. Hasil wawancara bersama siswa memperoleh hasil jika siswa tertarik jika belajar dengan menggunakan laptop. Siswapun mengakui bahwa mereka dapat mengoperasikan laptop maupun komputer, siswa mengaku belum pernah belajar tentang kebudayaan asli di Kabupaten Berau apalagi dengan menggunakan multimedia.

Hasil wawancara dengan guru selaku praktisi pendidikan mengungkapkan jika, guru mengalami kesulitan dalam mengajarkan kebudayaan di Kabupaten Berau karena belum tersedianya buku penunjang khusus membahas materi tentang budaya di Berau. tingginya tuntutan jam mengajar yang harus diselesaikan di kelas membuat guru mengalami kesulitan jika harus mengembangkan multimedia untuk pembelajaran. guru pernah mencari materi berkaitan dengan kearifan lokal Kabupaten Berau dengan menggunakan internet namun belum secara spesifik, guru pernah memanfaatkan fasilitas IT yang ada di sekolah untuk menampilkan media yang sederhana dan mudah, seperti menampilkan gambar maupun video saja. Berdasarkan hasil analisis kebutuhan, penelitian merancang suatu produk multimedia interaktif yang menarik minat belajar siswa dan berkaitan dengan kearifan lokal di Kabupaten Berau.

Proses pengembangan produk multimedia interaktif dengan membuat story board, story board merupakan cetak biru dari produk yang dikembangkan memuat deskripsi terperinci berkaitan dengan elemen gambar, suara, video, animasi, serta materi-materi pembelajaran yang dimuat di dalam produk aplikasi multimedia interaktif. Proses penggabungan dari masingmasing elemen media mengacu kepada story board yang telah dirancang. Produk multimedia interaktif berbasis kearifan lokal yang telah selesai dikembangkan harus melewati uji kelayakan melalui proses validasi yang dilakukan oleh validator ahli media dan ahli materi, kedua validator tersebut merupakan penguji yang menentukan secara keseluruhan baik dari segi tampilan media maupun segi isi materi yang diinternalisasikan di dalam produk multimedia interaktif. Hasil uji yang dilakukan selama proses uji kelayakan oleh validator ahli media memperoleh hasil data dengan total persentase skor hasil sebesar $98,26 \%$, sedangkan untuk uji kelayakan oleh validator ahli materi memperoleh hasil data dengan total persentase skor sebesar 93.68\%. Berdasarkan persentase skor tersebut maka produk multimedia telah siap untuk dilanjutkan ke tahap uji coba lanjutan ,dengan mengacu kepada pendapat (Akbar, 2017) rentang persentase 85.01-100\% produk sangat valid dan dapat digunakan tanpa perbaikan.

\section{Penyajian Data Hasil Uji Coba Kelompok Kecil}

Uji coba kelompok kecil dilaksanakan di SDN 002 Tanjung Redeb dilakukan oleh delapan orang siswa kelas IVB yang dipilih berdasarkan tingkat kemampuan yang berbeda-beda mulai dari siswa dengan tingkat kemampuan tinggi, sedang, dan rendah. Uji coba kelompok kecil dilakukan untuk memperoleh data terkait aspek kemenarikan dan kepraktisan dari produk multimedia interaktif berbasis kearifan lokal Kabupaten Berau. Persentase perolehan data hasil kemenarikan mencapai 90,31\% dengan kriteria sangat menarik. Perolehan data hasil kepraktisan mencapai $92,81 \%$ dengan kriteria sangat praktis. Hasil rekapitulasi data yang diperoleh dari selama melaksanakan uji coba kelompok kecil dipaparkan pada tabel 3. 
Tabel 3. Hasil Rekapitulasi Uji Coba Kelompok Kecil

\begin{tabular}{clc}
\hline Subjek & \multicolumn{1}{c}{ Aspek } & Hasil \\
\hline \multirow{2}{*}{ Delapan orang siswa kelas IV } & Kemenarikan & $90,31 \%$ \\
& Kepraktisan & $92,81 \%$
\end{tabular}

Hasil uji kelompok kecil untuk mengetahui respons siswa terhadap produk multimedia interaktif berbasis kearifan lokal memperoleh hasil sesuai dengan yang diharapkan. Menurut pendapat (Akbar, 2017) suatu produk dapat dikatakan memenuhi kriteria kemenarikan dan kepraktisan jika berada pada rentang persentase $85.1-100 \%$. Berdasarkan tabel 3, hasil yang diperoleh dapat disimpulkan bahwa produk multimedia ini telah sesuai dengan kriteria tanpa perlu adanya perbaikan dan dapat dilanjutkan untuk melakukan uji coba lapangan.

\section{Penyajian Data Hasil Uji Coba Lapangan}

Uji coba lapangan yang dilakukan oleh 28 orang siswa kelas IVC, hasil data untuk aspek kemenarikan memperoleh persentase mencapai 98,4\% dengan kriteria sangat menarik. Pada perolehan hasil data untuk aspek kepraktisan memperoleh persentase mencapai $97,4 \%$ dengan kriteria sangat praktis. Produk multimedia interaktif berbasis kearifan lokal Kabupaten Berau yang di uji coba lapangan memenuhi kriteria sangat praktis, Hasil rekapitulasi data yang diperoleh dari selama melaksanakan uji coba lapangan dipaparkan pada tabel 4.

\section{Tabel 4. Hasil Rekapitulasi Uji Coba Lapangan}

\begin{tabular}{clc}
\hline \multicolumn{1}{c}{ Subjek } & \multicolumn{1}{c}{ Aspek } & Hasil \\
\hline \multirow{2}{*}{ 28 orang siswa kelas IVC } & Kemenarikan & $98,4 \%$ \\
\cline { 2 - 2 } & Kepraktisan & $97,4 \%$
\end{tabular}

Hasil uji coba lapangan respon yang ditunjukan selama proses pembelajaran dengan menggunakan multimedia interaktif berbasis kearifan lokal Kabupaten Berau sesuai dengan yang diharapkan. Sehingga produk yang dikembangkan merupakan produk layak untuk digunakan untuk menunjang proses pembelajaran. Menurut pendapat (Akbar, 2017) suatu produk dapat dikatakan memenuhi kriteria kemenarikan dan kepraktisan jika berada pada rentang persentase $85.1-100 \%$. Selain melakukan pengumpulan data terhadap siswa, peneliti juga melakukan pengumpulan data respons guru selaku praktisi pendidikan yang menggunakan multimedia interaktif ini selama proses pembelajaran. Adapun hasil penilaian data respons praktisi dipaparkan pada tabel 5 .

Tabel 5. Hasil Penilaian Respons Praktisi

\begin{tabular}{lll}
\hline Indikator penilaian kemenarikan & Kesesuaian Multimedia Interaktif dengan Materi Pembelajaran & Persentase Skor \\
\cline { 2 - 3 } & Kemenarikan tampilan dan isi multimedia interaktif & $94 \%$ \\
\hline Indikator penilaian kepraktisan & $\begin{array}{l}\text { Kesesuaian isi dengan multimedia interaktif dengan materi pembelajaran } \\
\text { Kepraktisan penggunaan multimedia interaktif }\end{array}$ & $94.28 \%$ \\
\hline
\end{tabular}

Berdasarkan hasil data penilaian respons praktisi pendidikan atau guru kelas IV sebagai pengguna produk multimedia interaktif berbasis kearifan lokal Kabupaten Berau dalam kegiatan pembelajarannya di kelas. Pengumpulan data dengan menggunakan angket respons yang meliputi aspek kemenarikan dan aspek kepraktisan. Diperoleh hasil data pada aspek kemenarikan mencapai 94\% sangat menarik dan perolehan hasil data pada aspek kepraktisan mencapai 94,28\% sangat praktis.

\section{Penyajian Data Keefektifitasan Multimedia Interaktif}

Uji keefektifan merupakan bagian dari uji lapangan yang bertujuan untuk memperoleh hasil data keefektifan produk multimedia interaktif berbasis kearifan lokal selama digunakan sebagai media penunjang proses pembelajaran. Uji keefektifan dilakukan di kelas IV SDN 002 Tanjung Redeb dengan jumlah siswa 28 orang siswa secara heterogen. Instrumen yang digunakan untuk pengumpulan data menggunakan instrumen tes multiple choice yang dilakukan pada saat pembelajaran sebelum menggunakan multimedia interaktif dan setelah melakukan pembelajaran menggunakan multimedia interaktif (Pre-test dan Post-test). Soal yang terdapat pada lembar tes evaluasi sebanyak 20 soal yang mencakup materi-materi muatan pembelajaran IPS pada tema 8 Daerah Tempat Tinggalku. materi pembelajaran tersebut telah diinternalisasikan dengan materi kearifan lokal di daerah Kabupaten Berau. adapun hasil pre-test dan post-test untuk melihat keefektifitasan siswa dalam pembelajaran dipaparkan pada tabel 6 . 
Tabel 6. Hasil pre-test dan post-test siswa

\begin{tabular}{lll}
\hline \multicolumn{1}{c}{ Data } & Pre-Test & Post-Test \\
\hline Rata-Rata Skor & 53,21 & 86,78 \\
Persentase Hasil Evaluasi & $53,21 \%$ & $86,78 \%$ \\
\hline
\end{tabular}

Berdasarkan tabel 6 dengan kriteria ketuntasan minimal hasil belajar yang ditetapkan sekolah yakni 70. Hasil data yang diperoleh dari evaluasi pada saat pre-test nilai siswa rata-rata sejumlah 53,21 dengan persentase hasil evaluasi mencapai $53,21 \%$. Perolehan hasil data dari evaluasi yang dilakukan pada saat post-test terlihat peningkatan yang terjadi dimana nilai rata-rata siswa sejumlah 86,78 dengan persentase hasil evaluasi mencapai $86,78 \%$. Terlihat peningkatan dari hasil belajar yang dilakukan oleh siswa sebelum belajar menggunakan multimedia interaktif berbasis kearifan lokal dan setelah belajar menggunakan multimedia interaktif. menurut (Akbar, 2017) dengan persentase berada pada rentang nilai $85,01-100 \%$ dimana pada rentang nilai tersebut produk multimedia interaktif yang dikembangkan memenuhi kriteria sangat efektif. sehingga dapat disimpulkan bahwa multimedia interaktif berbasis kearifan lokal Kabupaten Berau pada muatan pembelajaran IPS untuk siswa kelas IV sekolah dasar sangat efektif dan dapat digunakan untuk kegiatan pembelajaran.

\section{SIMPULAN}

Internalisasi kearifan Kabupaten Berau melalui pengembangan media penunjang pembelajaran dalam bentuk multimedia interaktif yang dilakukan di kelas IV pada SDN 002 Tanjung Redeb di Kabupaten Berau dinilai berhasil. Keberhasilan tersebut diukur berdasarkan respons positif siswa dan guru tentang kepraktisan dan kemenarikan multimedia interaktif berbasis kearifan lokal Kabupaten Berau. Produk multimedia interaktif berbasis kearifan lokal Kabupaten Berau dinilai layak, menarik dan praktis untuk digunakan dalam pembelajaran oleh praktisi yakni guru kelas IV SDN 002 Tanjung Redeb. Berdasarkan hasil uji coba kelompok kecil dan pengisian angket yang dilakukan pada siswa dan guru, multimedia interaktif berbasis kearifan lokal Kabupaten Berau dinilai menarik dan praktis untuk menunjang pembelajaran yang bermakna.

Proses konstruksi dari pengetahuan yang sudah ada tentang budaya di daerah Kabupaten Berau terjadi lebih besar setelah menciptakan pembelajaran kontekstual dengan multimedia interaktif berbasis kearifan lokal. Pengembangan produk multimedia interaktif berbasis kearifan lokal Kabupaten Berau yang digunakan guru kelas IV SDN 002 Tanjung Redeb di Kabupaten Berau mampu untuk meningkatkan hasil belajar siswa tentang materi-materi yang berhubungan dengan tema 8 Daerah Tempat Tinggalku. Hal ini membuktikan bahwa proses internalisasi kearifan lokal Kabupaten Berau dengan menggunakan media yang menarik dalam pembelajaran dapat meningkatkan antusias siswa dalam belajar. Selain itu, multimedia interaktif berbasis kearifan lokal ini dapat menjadi media pendukung yang sangat menarik sesuai dengan kemajuan teknologi untuk digunakan saat proses pembelajaran di kelas. Untuk mengenalkan kearifan lokal budaya yang ada di wilayah Kabupaten Berau.

Seiring dengan kemajuan zaman di era globalisasi ini berbanding lurus dengan semakin meningkat akan kebutuhannya perangkat teknologi informasi menggunakan perangkat digital yang semakin canggih, menarik serta memudahkan aktivitas. Hal tersebut tidak hanya dapat membawa pengaruh positif namun juga dapat membawa pengaruh negatif, khususnya kepada karakter bangsa yang memiliki budaya dan adat istiadat warisan nenek moyang dalam bentuk kearifan lokal di masing-masing daerah. Revitalisasi dan penguatan nilai-nilai karakter bangsa Indonesia yang termuat di dalam kearifan lokal tersebut hendaknya harus terus diajarkan dalam dunia pendidikan. Hal ini dilakukan demi mempersiapkan generasi emas yang tidak hanya melek terhadap teknologi, tetapi juga mampu menjaga nilai dan norma-norma dalam masyarakat sebagai makhluk sosial sehingga lahirlah kehamornisan dan kerukunan dalam masyarakat. internalisasi nilai-nilai luhur yang merupakan warisan kearifan lokal sudah seharusnya terus dikembangkan untuk mampu bersaing di era modern ini dan demi menjaga amanah leluhur yang diwariskan dalam budaya dan kearifan lokal serta untuk tetap menjaga karakter bangsa Indonesia sebagai bangsa yang memiliki suku bangsa dan agama yang berbeda-beda, namun tetap dapat hidup rukun di bawah naungan bendera merah putih.

Pengembangan media dalam pembelajaran merupakan tanggung jawab seorang pendidik. Pengembangan media pendukung pembelajaran hendaklah mengacu pada buku nasional yang sudah ada dengan mempertimbangkan kebutuhan belajar siswa, sumber belajar yang bermakna dan ketersediaan sarana dan prasarana di sekolah. Oleh karena itu, perlu kerjasama yang baik dari berbagai pihak baik guru, kepala sekolah, siswa, orangtua siswa, pemerintah, dan masyarakat untuk mengembangkan pendidikan Indonesia dan mempertahankan kearifan lokal yang sudah ada. 


\section{DAFTAR RUJUKAN}

Akbar, S. (2017). Instrumen Perangkat Pembelajaran. Bandung: Rosda Karya.

Damayanti, C., Dewi, N, R., \& Akhlis, I. (2013). Pengembangan CD Pembelajaran Berbasis Kearifan Lokal Tema Getaran dan Gelombang untuk Siswa SMP Kelas VIII. Unnes Science Education Journal, 2(2), 274-281. https://doi.org/doi.org/10.15294/usej.v2i2.2036

Jossapat, Hendra, P. (2015). Kompetensi Kepribadian Guru dan Relevansinya terhadap Tugas Mengajar di Sekolah. Jurnal Pendidikan Dompet Dhuafa. Divisi Penelitian dan Pengembangan Makmal Pendidikan, Bumi Pengembangan Insani, 5(2).

Kaltim Prokal. (2016). Manguati Banua di Gunung Tabur Pertahankan Tradisi jadi Daya Tarik Pariwisata. http://kaltim.prokal.co/read/news/276365-manguati-banua-di-gunung-tabur)

Khuriyah, L., Utaya, S., \& Sapto, A. (2016). Kontribusi Tradisi Erau Sebagai Sumber Pembelajaran Kontekstual IPS. In Pengembangan Profesionalisme Pendidikan untuk Membangun Karakter Anak Bangsa. Malang: Universitas Negeri Malang. Retrieved from http://pasca.um.ac.id/conferences/index.php/gtk/article/view/265/249

Komalsari, K. (2014). Pembelajaran Kontekstual: Konsep dan Aplikasi. Bandung: Refika Utama.

Munir. (2013). Multimedia: Konsep dan Aplikasi dalam Pendidikan. Yogyakarta: Pustaka Pelajar.

Noviana, E., \& Bakri, R, M. (2015). Implementasi Bahan Ajar Pendidikan Ilmu Sosial Berbasis Kearifan Lokal di Kelas IV Sekolah Dasar Negeri 04 Buantan Besar Kecamatan Siak Kabupaten Siak. Jurnal Primary: Jurnal Pendidikan Guru Sekolah Dasar, 4(1). https://doi.org/dx.doi.org/10.33578/jpfkip.v4i1.2716

Panen, P., \& Sardiyo. (2005). Pembelajaran Berbasis Budaya: Model Inovasi Pembelajaran dan Implementasi Kurikulum Berbasis Kompetensi. Jurnal Pendidikan (Universitas Terbuka), 6(2), 83-98.

Rosidi, A. (2011). Kearifan Lokal dalam Persepektif Budaya Sunda. Bandung: Kiblat Buku Utama.

Rusman. (2010). Teknologi Informasi dan Komunikasi dalam Pembelajaran. Bandung: Universitas Pendidika Indonesia.

Sudikan, S. Y. (2013). Kearifan Budaya Lokal. Sidoarjo: Damar Ilmu.

Sugiyono. (2015). Metode Penelitian Kuantitatif, Kualitatif, dan R\&D. Bandung: Alfabeta.

Sukmawati, Utaya, S., \& Susilo, S. (2015). Kearifan Lokal Masyarakat Adat dalam Pelestarian Hutan sebagai Sumber Belajar Geografi. Jurnal Pendidikan Humaniora, 3(3), 202-208.

Sumarmi, \& Amirudin. (2014). Geografi Lingkungan Berbasis Kearifan Lokal. Malang: Aditya Media Publishing.

Suwaryo. (2008). Peranan Organisasi Perguruan Seni Beladiri Pencak Silat dalam Meminimalisir Kejahatan (Studi Suatu Upaya Non-Penal Pada Organisasi Perguruan Seni Beladiri Pencak Silat di Kabupaten Banjarnegara, Provinsi Jawa Tengah). Universitas Diponegoro. Retrieved from http://eprints.undip.ac.id/17800/1/Suwaryo.pdf

Utari, U., \& Degeng, I. N. S. (2016). Pembelajaran Tematik Berbasis Kearifan Lokal di Sekolah Dasar dalam Menghadapi Masyarakat Ekonomi Asean (MEA). Jurnal Teori dan Praksis Pembelajaran IPS, 1(1), 39-44. 